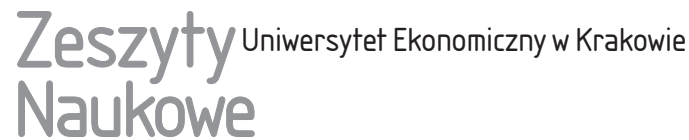

\section{Centra i peryferie jako rama analityczna i pojeciowa*}

\section{Streszczenie}

Celem artykułu jest zbadanie, na ile rama centrów i peryferii jest teoretycznie i praktycznie użyteczna jako narzędzie analityczne i wyjaśniające procesy koncentracji i polaryzacji przestrzennej, społecznej, kulturowej (w tym symbolicznej), politycznej i ekonomicznej.

Artykuł składa się z dwóch części. W pierwszej przeanalizowano teoretyczne zagadnienia związane ze stosowaniem pojęć centrum i peryferii. Zauważono problem z arbitralnością tych pojęć, obecność licznych, niewyrażanych wprost założeń dodatkowych oraz pretendowanie tej ramy do uniwersalności. W drugiej części artykułu zbadano możliwości stworzenia czytelnej typologii centrów i peryferii na podstawie dominujących procesów i składających się na nie zjawisk obserwowalnych. Artykuł ma charakter metateoretyczny, przeglądowy i zmierza do określenia dalszych kierunków badań nad centro-peryferyjnością.

W rezultacie analizy sformułowano listę obserwowalnych kategorii składających się na opis centrów i peryferii, które mogą służyć jako podstawa typologizacji i operacjonalizacji w badaniach empirycznych. Kategoria „kompensacja peryferyjności” wydaje się szczególnie istotna dla badań. Kompensowanie peryferyjności potwierdza bowiem status peryferii i ujawnia kierunek relacji dominacji.

Słowa kluczowe: centrum, peryferie, kompensacja peryferyjności, rozwój.

Katarzyna Kwarcińska, Uniwersytet Ekonomiczny w Krakowie, Wydział Gospodarki i Administracji Publicznej, Katedra Socjologii, ul. Rakowicka 27, 31-510 Kraków, e-mail: kwarcink@uek. krakow.pl

* Artykuł powstał w ramach badań statutowych Katedry Socjologii finansowanych ze środków własnych przez Uniwersytet Ekonomiczny w Krakowie. 


\section{Wprowadzenie}

Celem artykułu jest analiza pojęć centrów i peryferii w aspekcie ich teoretycznej i praktycznej użyteczności w badaniach nad procesami koncentracji i polaryzacji przestrzennej, społecznej, kulturowej (w tym symbolicznej), politycznej i ekonomicznej. W naukach społecznych posługujemy się wieloma pojęciami urobionymi arbitralnie, nieposiadającymi zobiektywizowanych kryteriów odróżniania ich zakresów, trudnymi do zoperacjonalizowania i opartymi na ukrytych założeniach. Występowanie tych cech w aparacie pojęciowym nauk społeczno-politycznych, a nawet ekonomicznych, nie jest czymś dyskwalifikującym. Nawet brak wolności od wartościowania nie eliminuje z użycia pojęć na gruncie tych nauk. Swoboda w urabianiu pojęć w naukach społecznych może jednak prowadzić do ich inflacji i dewaluacji dyscypliny, w ramach której są stosowane. Autorka dostrzega konieczność analizy pojęciowej poprzedzającej badania teoretyczne i empiryczne w naukach społecznych ${ }^{1}$. Jej celem nie jest krytyka tych pojęć od strony merytorycznej ani ustosunkowanie się do bogatej dyskusji teoretycznej na temat rozwoju, niedorozwoju, dyfuzji rozwoju lub innych koncepcji odwołujących się do założenia polaryzacji w relacjach geopolitycznych (np. teoria zależności, teoria dyfuzji rozwojowej).

Centra i peryferie należą do szerszych ram dyskursywnych, w których rozważa się zagadnienie rozwoju społecznego, politycznego i gospodarczego, problematykę wykluczenia, regionalnych zróżnicowań i nierówności, teorię konfliktów i ruchów społecznych. Są to zagadnienia z długą tradycją i dorobkiem, które podzielają metateoretyczne i metapojęciowe trudności, z jakimi można się spotkać, posługując się pojęciami centrów i peryferii. Żadne z nich nie jest jednak wolne od poznawczych zniekształceń związanych z odwoływaniem się do potocznych skojarzeń i wartościowań (np. rozwój jest pozytywny, wykluczenie złe, centra są silne, peryferie słabe itp.). Łatwo o pominięcie opisowej i porządkującej użyteczności, zwłaszcza gdy każde z tych pojęć może zostać użyte w walce politycznej lub ideologicznej, której celem nie jest wyjaśnianie, ale przekonanie przeciwnika do własnych racji. W aspekcie empirycznym istnieje konieczność zmierzenia się z całym szeregiem trudności związanych z próbami projektowania empirycznego badania zależności centro-peryferyjnych w realnych układach społecznych, geograficznych, politycznych i ekonomicznych.

Zwraca się też uwagę na występowanie luki teoretycznej i metateoretycznej w obszarach peryferyjnych (peryferyjności nauki) oraz zjawisko (neo)imperializmu metodologicznego. Wydaje się, że jedną z cech peryferii jest unikanie

${ }^{1}$ Przykładem tego typu dyskusji jest opracowywanie pojęć hegemonii i imperializmu, wyjaśnienie rozbieżności w ich rozumieniu, wypracowywanie wspólnego zrębu pojęciowego [Chasse-Dunn i in. 1994]. 
samodzielnej refleksji teoretycznej i metateoretycznej oraz zapożyczanie wniosków i kluczowych definicji teoretycznych i metateoretycznych urabianych w obszarach rdzenia (przede wszystkim w Stanach Zjednoczonych). Wprowadza to znaczącą asymetrię już na poziomie autoanalizy i samoopisu zarówno centrów, jak i peryferii, która postępuje i przeradza się w proces marginalizacji osiągnięć badawczych peryferii. Co więcej, peryferie stają się głównym środkiem do rozprzestrzeniania wiedzy z centrów i na temat centrów, same pozostają natomiast w ,intelektualnym cieniu” [Latour 1999, Losego i Arvanitis 2008, Tickner 2013].

Artykuł składa się z dwóch części. Pierwsza zawiera analizę teoretycznych zagadnień związanych ze stosowaniem terminów „centrum” i „peryferie”, takich jak arbitralność tych pojęć, obecność licznych, niewyrażanych wprost założeń dodatkowych oraz pretendowanie tej ramy do uniwersalności. W drugiej części skupiono się na możliwości stworzenia typologii centrów i peryferii przez zidentyfikowanie procesów i zjawisk obserwowalnych. Ta część nie ma charakteru empirycznego lub badawczego, więc nie należy od niej oczekiwać metodologicznej precyzji. Ma ona charakter badawczego rekonesansu, którego celem jest zorientowanie się, jaki jest teoretyczny i empiryczny potencjał zagadnień - zakres możliwych kierunków badań, co ma poprzedzać decyzje dotyczące wyboru niektórych z nich.

\section{Arbitralność}

Kategorie centrum i peryferii wywodzą się z nurtu teorii określanych wspólną etykietą teorii rozwoju zależnego, teorii niedorozwoju lub teorii spolaryzowanego rozwoju. Teorie te stawiały sobie za cel m.in. odpowiedź na pytanie, dlaczego pewne jednostki (np. państwa, regiony) nie zdołały dogonić tych o wyższym poziomie rozwoju. Przeciwnicy teorii spolaryzowanego rozwoju zwrócili uwagę na to, że samo postawienie pytania w taki sposób sugeruje arbitralny podział na bardziej i mniej właściwe (wartościowe) sposoby funkcjonowania porównywanych jednostek. Rodzi to szereg wątpliwości dotyczących ewaluacji tego, co rozwojowe, i pytań, jakiego typu funkcjonowanie należy uznać za bardziej odpowiednie i kto ma prawo dokonywać takiej oceny. Tworzenie obiektywnych i subiektywnych list parametrów rozwoju okazuje się w praktyce dość skomplikowane (np. pojawia się skłonność do fetyszyzacji liczb) [Payne i Philips 2011]. Kontrowersje wzbudza również podstawa porównań, która powinna dotyczyć równoległych parametrów. Tymczasem występują w ramach tej podstawy zasadnicze empiryczne różnice. Jednostki zaliczane do rozwiniętych nigdy w swojej przeszłości nie przechodziły przez okres niedorozwoju, a więc stawianie ich za wzór tym jednostkom, które obecnie w niedorozwoju się znajdują, jest nieadekwatne nawet na gruncie 
samych teorii doganiania i teorii rozwoju zależnego (jednostki doganiane nie mają w swojej historii niczego, co stosowałoby się do sytuacji współczesnych jednostek w niedorozwoju, doganiających, i z czego te ostatnie miałyby korzystać) [Frank 1966].

Zwracano także uwagę, że wymóg doganiania formułowany w odniesieniu do obszarów peryferyjnych traktuje je jako w pełni odpowiedzialne za kreowanie ścieżek własnego rozwoju. Uznawano to za nieścisłość, gdyż państwa i regiony nie egzystują ani nie działają w gospodarczej, społecznej oraz ekonomicznej próżni. Należy więc oceniać także kontekst funkcjonowania analizowanej jednostki (czy sprzyja on rozwojowi), a nie tylko jej wewnętrzne walory. Rozwój danego obszaru zawsze w jakimś stopniu zależy od otoczenia, w którym przebiega [Payne i Philips 2011]. Jedną z determinujących cech tego kontekstu jest przekonanie, zgodnie z którym rozwój jednostek peryferyjnych i zmniejszenie polaryzacji może oznaczać uszczuplenie pozycji obszarów rdzenia i ich delegitymizację. Stąd też układy centralne dążą do arbitralnego narzucenia swoim satelitom definicji rozwoju, centralności i peryferyjności, kreując swoją własną ścieżkę na wzorcową i stan, jaki udało się im osiągnąć, na docelowy i pożądany dla wszystkich [Lipset i Rokkan 1967, Zarycki 2009]. W zamian peryferie zyskują zdolność do ustabilizowania swojej sytuacji w relacji do centrum i przez nią oraz - jak przekonują zwolennicy koncepcji „biegunów wzrostu” - otrzymują impuls rozwojowy [Perroux 1950] lub/i możliwość konsumpcji nadwyżek pochodzących z centrów. Wiąże się z tym również przekonanie, że w takich warunkach dobrobyt udzieli się peryferiom niejako samoczynnie [Payne i Philips 2011].

Te potencjalne korzyści nie podważają jednak stwierdzenia arbitralności podziału na centrum i peryferie oraz, w konsekwencji, przyjęcia definicji sytuacji skonstruowanych w obrębie rdzenia i przenoszonych na obrzeża. Nawet jeśli peryferie otrzymają pozytywne impulsy, będą to impulsy ukierunkowujące je na powtórzenie modeli centrów i próbę ich doganiania. Konsumpcja nadwyżek niewątpliwie korzystna w krótkiej perspektywie i prowadząca do szybkiego skoku jakości życia może okazać się czynnikiem hamującym dla procesu samodzielnego szacowania korzyści oraz stworzenia autonomicznych modeli rozwojowych, bardziej społecznie i kulturowo adekwatnych. W aspekcie psychologicznym i społecznym transfer zasobów z lepiej sytuowanych ośrodków do ich satelitów przynajmniej do pewnego stopnia determinuje sposób definiowania potrzeb, wpływa na poczucie relatywnej deprywacji i percepcję nierówności [Wilkinson i Pikket 2011]. Centra stają się w ten sposób nie tylko ośrodkami regulacji dystrybucji zasobów gospodarczych i władzy politycznej, ale również punktem odniesienia dla sądów wartościujących, hierarchizacji i porządkowania poznawczego rzeczywistości, regulatorem przestrzeni symboliczno-kulturowej. Arbitralność podziału na centrum i peryferie przenoszona jest na różne obszary funkcjono- 
wania, w tym społeczne i indywidualne systemy aksjonormatywne oraz hierarchizowanie potrzeb i priorytetów. Dyskusyjnym przykładem takiej arbitralnej ingerencji centralnego systemu w system aksjonormatywny i hierarchie potrzeb lokalnych układów peryferyjnych mogą być programy pomocy rozwojowej, których uruchomienie uwarunkowane jest zmniejszeniem dzietności regionu rozwijającego się przez wdrożenie programów regulacji poczęć [Bloom i Canning 2009]. Propozycja takiej „wiązanej transakcji” świadczy o próbie ingerencji rdzenia nie tylko w obszar zaspokajania potrzeb, ale również obszar, w którym te potrzeby powstają. Kulturowe normy, społeczne wartości peryferii, a także obszary indywidualnych wolności jednostek je zamieszkujących zostają zanegowane i potraktowane jako sprzeczne z wartościami, normami i wyborami wartości zdefiniowanych jako rozwojowe przez centrum. W zasadzie każda sytuacja sprzeciwu w przyjmowaniu wzorców centrum może skutkować przypisaniem jednej z etykiet peryferyjności i jakimś rodzajem wykluczenia (czasowego - przeżytek; przestrzennego - margines, getto; kulturowego - zaścianek, ciemnogród) [Jałowiecki i Kapralski 2011, Kurczewska 2013]. W ten sposób społeczności peryferyjne zostają pozbawione możliwości zdefiniowania własnych problemów na swój własny sposób oraz poszukiwania ich rozwiązań na własnych zasadach.

\section{Dodatkowe założenia}

Dychotomia centrów i peryferii opisuje nie tylko statyczną stronę zróżnicowań. Rdzeń i obrzeża funkcjonują jako bieguny niesymetrycznej relacji charakteryzowanej jako jednokierunkowa zależność, dominacja, a czasem wręcz wyzysk [Pogonowska 2007], istnieją też stanowiska akcentujące konfliktowy charakter tych układów [Zarycki 2002]. Rzadziej zwraca się uwagę na komplementarność członów lub korzyści wynikające z powiązań obrzeży z rdzeniem [Kisiała i Stępiński 2013]. Domyślne założenia o kumulacji przewag po stronie centrum i deficytach po stronie peryferii są na tyle silnie zakorzenione, że nawet nie podejmuje się prób ich ujawniania i uzasadniania. Przekonanie o niższości cywilizacyjnej, zacofaniu i wadliwości obecne jest nie tylko w myśleniu potocznym, politycznym czy ideologicznym, lecz także naukowym. Co więcej, niektóre nurty badawcze zdają się szczególnie podkreślać nieusuwalność dysfunkcjonalności peryferii nawet w dłuższym horyzoncie czasowym. Kształtuje się w ten sposób schemat poznawczy, którego wyznacznikiem jest upośledzenie cywilizacyjne peryferii i normatywny standard rozwoju wyznaczany przez centra. Na jego podstawie w coraz bardziej systematyczny sposób powielany jest mit centrów kontrastowany z mitem prowincji. 
Ważną grupę założeń dodatkowych, na których oparta jest rama centrumperyferie, stanowią przekonania dotyczące projektu nowoczesności. Nowoczesność centrów nigdy nie jest kwestionowana, ale przecież sama również wymaga dookreślenia. Pojęcie nowoczesności jest stopniowalne i zrelatywizowane kulturowo. Może wyrażać ekspresję oczekiwań i życzeń (postulatów) względem rzeczywistości i wówczas nie powinno być traktowane jako opis rzeczywistości (choć niekiedy tak się dzieje). Nowoczesność zazwyczaj wartościowana jest pozytywnie, co nobilituje także powiązaną z nią centralność. Peryferie zyskują swoje definicje przez zaprzeczenie centralności i nowoczesności (wszystko, co nie jest centrum, jest peryferiami) i w tym aspekcie można mówić o stygmatyzującym charakterze pojęć centralności i peryferyjności [Bajerski 2006].

Z drugiej strony, konstrukcja pojęcia nowoczesności może stać się punktem wyjścia do krytyki analizy opartej na kategoriach centralności i peryferyjności. Nowoczesność w tym przypadku odwołuje się do wyobrażenia społeczeństw zunifikowanych tak dalece, że kategorie przestrzennych zróżnicowań przestają się do nich stosować. W myśl teorii modernizacji w jednorodnej przestrzeni zróżnicowania państwowe, lokalne i regionalne miały stopniowo tracić na znaczeniu, a wreszcie zaniknąć. W logice modernizacji ujednolicenie obszarów uznawane było za proces głęboko racjonalny, w którym peryferie podporządkowują się przewadze rdzenia, dostrzegając w tym dla siebie potencjał rozwojowy, i na rzecz jego wykorzystania rezygnują ze swoich unikatowych tożsamości [Zarycki 2009]. Ta wizja rywalizowała z obrazem rzeczywistości jako mozaiki różnorodnych, niepowtarzalnych miejsc z ich historiami, symbolami i subiektywnymi opowieściami. W tej wizji również hierarchiczny porządek centro-peryferyjny nie ma racji bytu, gdyż elementy mozaiki są nieporównywalne. Inną ramą, alternatywną dla centro-peryferyjnej, miała stać się rama globalizacji. Globalizacja jako siła unifikująca nie za pośrednictwem centrów politycznych, lecz przez międzynarodowe podmioty gospodarcze miała działać zgodnie z logiką sieci, w której przestrzeń traci na znaczeniu. Jeśli niektóre jednostki w reakcji na uwikłanie w globalne sieci zareagują wzmocnieniem swoich regionalnych i lokalnych tożsamości, dojdzie do dialektycznego połączenia lokalnego i globalnego wymiaru, do „glokalizacji”. W tym układzie również podział centro-peryferyjny nie wydaje się odpowiedni [Zarycki 2009].

Zastosowanie centro-peryferyjnej ramy odsyła przede wszystkim do teorii rozwoju zależnego. Można się zastanawiać, czy nie jest to perspektywa zniekształcająca wizję rozwoju, pomijająca wewnętrzne i zindywidualizowane aspekty badanej jednostki, koncentrująca się na porównaniu z zewnętrznymi odniesieniami. Modernizacja tego typu wikła się w sprzeczność takiej natury, że to, co centralne, musi wytworzyć peryferyjność, a nowoczesność nie istnieje bez zacofania, co oznacza proces nieustannego konstruowania symboliczno-mentalnej ramy negatywnego odniesienia [Jałowiecki i Kapralski 2011]. 


\section{Uniwersalność}

Rama centrów i peryferii pretenduje do rangi uniwersalnego narzędzia opisu i analizy. Sprawia wrażenie pozaprzestrzennej, pozaczasowej oraz adekwatnej na wszystkich poziomach analizowanych jednostek (globalny, regionalny, państwowy, lokalny, teraźniejszy, dawny, przyszły). Tymczasem nie jest łatwo określić, w jakim stopniu operacjonalizacja tych pojęć prowadzi do wykrywania i opisywania istniejących zależności, a w jakim je kreuje. Charakter obszaru, który podlega badaniu, nie jest obojętny dla formułowania i zasięgu wyjaśnień zależności i zróżnicowań. Nośniki zróżnicowań stale się zmieniają i w praktyce badawczej lista czynników powinna być aktualizowana. Oznacza to, że relacje centro-peryferyjne stwierdzone i opisane w jednym kontekście nie zawsze multiplikują się w innych, a raz postawione wnioski nadają się do ekstrapolowania na relacje stwierdzone gdzie indziej.

Na centralność i peryferyjność składa się kilka wymiarów. Pozostają one względem siebie w różnorodnych relacjach, tworząc modalności unikatowe dla każdego z układów. Charakteryzowanie ich może zostać dokonane przez wskazanie stopnia odległości, odmienności i zależności peryferii od centrum [Jałowiecki i Kapralski 2011]. Inną propozycją typologii czynników przesądzających o peryferyjności jest zaproponowana przez S. Eisenstadta lista kryteriów, na którą składają się stopień zgodności pomiędzy kulturowymi i politycznymi tożsamościami społeczności lokalnych i centralnych, stopień zaangażowania peryferii w życie kulturalne centrów, rola centrów w definiowaniu celów społeczności lokalnych, dostępność do zasobów centrów dla przedstawicieli społeczności peryferii [Jałowiecki i Kapralski 2011]. Propozycje S. Lipseta i S. Rokkana [1967], S. Eisenstadta [2008] czy A. Hirschmanna [1958] kładą silny akcent na wymiar kulturowy. Autorzy ci polemizują z dość powszechnym przekonaniem, że to elementy ekonomiczne i polityczne odgrywają kluczową rolę w porządkowaniu układów centro-peryferyjnych. Elementy ekonomiczne i polityczne traktowane są jako bardziej racjonalne i dążące do spójności mającej zapewnić większą efektywność, dzięki czemu spełniają rolę silnie unifikującą obrzeża z rdzeniem. Tymczasem kultura i tożsamość są raczej czynnikami zakłócającymi proces scalenia oraz rezerwuarem oporu peryferii przed dominacją centrów. Dlatego pełna analiza centralności i peryferyjności nie powinna pomijać żadnego z tych obszarów, ale badać ich krzyżujące się wpływy [Jałowiecki i Kapralski 2011]. Można tu ponownie odwołać się do wcześniejszego przykładu uzależnienia pomocy rozwojowej od programów kontroli płodności. Jeśli społeczność lokalna przywiązuje dużą wagę do społeczno-kulturowej roli rodziny, ingerencja centrum najprawdopodobniej spotka się z oporem i negacją na tej właśnie płaszczyźnie, choć cele ekonomiczne i polityczne będą raczej akceptowane. 
Można spotkać liczne próby stosowania ramy centrum i peryferii do opisów zależności innych niż makrostrukturalne, przeniesienia jej na grunt antropologiczny i jednostkowy. Oznaczałoby to zerwanie z ich uniwersalnym charakterem, wyszukiwanie tego, co odrębne i szczególne. Zainteresowaniem badaczy cieszy się szczególnie kategoria peryferyjności i pogranicza, która staje się samodzielna i niezależna od centrów. Peryferie i pogranicza w tego typu pracach są nobilitowane jako zasób życiowy (np. sprzyjający wymianie handlowej) albo jako rodzaj unikatowego doświadczenia tożsamościowego, obszar refleksji i doświadczenia niedostępny centrom [Jałowiecki i Kapralski 2011, Kurczewska 2013]. Peryferii nie można „zwiedzić”, dla przybyszów są one nieczytelne, rażą brakiem logiki, marnotrawstwem i nieefektywnością. Dopiero uznanie za „swojego” pozwala wniknąć w genius loci oraz zrozumieć racjonalność pewnych praktyk (np. sprzedawanie na sztuki papierosów w wiejskim sklepie). Centra z ich kosmopolitycznym systemem aksjonormatywnym i zunifikowanym językiem nie przystosowują do poradzenia sobie z odmiennością peryferii, przybysze mogą czuć się zagubieni w nieczytelnych dla nich praktykach pozbawionych jednoznacznych charakterystyk i definicji (liminalnych). Peryferyjność w wymiarze jednostkowym i antropologicznym wydaje się więc być przeciwieństwem uniwersalizmu, normalizowania. Dostęp do peryferii nie jest możliwy przez wspólny intelektualny klucz, ale dopiero $\mathrm{w}$ jednostkowym doświadczeniu, uczestnictwie, które jest z natury nieznormalizowane, ambiwalentne i odosobnione.

Rama centrów i peryferii zaistniała także w dyskursie religijnym. Po pierwsze, funkcjonuje jako rodzaj opisu wykluczenia i nierówności społecznych, ale bywa także stosowana jako formuła dychotomicznych warunków funkcjonowania, np. wolności i zniewolenia, demokracji i autorytaryzmu. Papieże Jan Paweł II i Franciszek opisują siebie jako „przybyszów z daleka”, co jest interpretowane nie tylko w kontekście dosłownego geograficznego dystansu, ale bardziej radykalnie - jako opowieść o innym świecie, którego nie da się przybliżyć zwykłymi słowami. Po drugie, jest to rodzaj metafory stosowanej w komunikacji instytucji religijnych z wiernymi. Peryferie oznaczają tutaj rodzaj kontestacji zgeneralizowanych i zuniformizowanych punktów widzenia. Franciszek w swoim przemówieniu inauguracyjnym zwraca uwagę na to, że zjawisko zmiany wiąże się z wyjściem poza kurtynę oficjalnych narracji i znaczeń. Zmianom przypisuje więc nie tylko fizyczny charakter (zmiana czegoś w coś innego, zmiana miejsca itp.), ale uwzględnia jeszcze zmianę sposobu patrzenia, ,,mentalne przemieszczenie się”, czyli wybranie innego niż zawsze punktu widzenia. Jeśli zatem dotąd perspektywa centrów wobec peryferii była podstawą podejmowania decyzji, dokonywania ocen, to zdaniem papieża istotą zmiany będzie przyjęcie perspektywy peryferii [Ferrara 2015]. Po trzecie, religia sama w sobie może być opisana za pomocą kategorii centrów i peryferii [Casanova 1994]. Religia może występować jako element 
światowego ładu, walki o unifikację lub walki o tożsamość (zarówno religia, jak i kategorie centrum-peryferie mają dialektyczny charakter).

\section{Operacjonalizowanie pojęć centrum i peryferii}

W tej części artykułu stworzona zostanie lista obserwowalnych kategorii składających się na opis centrów i peryferii. Na podstawie tej listy powstanie zarys typologizacji centrum i peryferii. Relacja centrum wobec peryferii jest najczęściej określana jako asymetria wpływu (dominacja) na korzyść rdzenia. Wymiary, w których występuje, dotyczą środowiska politycznego, ekonomicznego, kulturowego. Następnie wyodrębniony zostanie główny proces, przez który dominacja się przejawia. Każdy wymiar dominowania jest współcharakteryzowany przez określone procesy w obrębie peryferii - bycia zdominowanym. W każdym wymiarze dla peryferii ujęty jest też proces kompensacji peryferyjności. Procesom odpowiadają obserwowalne zjawiska. Jeśli tego rodzaju zjawiska zachodzą w obrębie analizowanej jednostki, sugeruje to, że mamy do czynienia z centrum lub peryferiami. W tabeli 1 podano przykłady takich zjawisk. Wszystkie informacje zawarte w tabeli mają charakter poglądowy i nie są ani argumentami na rzecz jakiejś tezy, ani danymi z badań. Służą one zademonstrowaniu tego, jakiego rodzaju dane mogą być poszukiwane w sposób metodyczny na dalszych etapach pracy za pomocą ramy centrum-peryferie. Jest to próba uporządkowania i zrozumienia charakteru pola badawczego i teoretycznego przed jego właściwą analizą. Zrozumienie, $\mathrm{z}$ jakiego rodzaju zagadnieniem mamy do czynienia przed przystąpieniem do jakichkolwiek badań, wydaje się istotne w przypadku operowania pojęciami o szerokich semantycznych granicach. W ten sposób można uniknąć zarówno nadmiernych oczekiwań związanych z pracą nad zagadnieniem, jak i rozczarowań związanych z ewentualnym rezultatem, a także bardziej refleksyjnie odnieść się do tego, co zostało już na dany temat powiedziane 2 .

Jeśli chodzi o dominację polityczną, zauważono dwa takie procesy - mobilizowanie peryferii do uznania centralnego systemu politycznego oraz kreowanie dyskursu politycznego. Zdominowanie polityczne ujawnia się według mnie w następujących procesach: niestabilnej legitymizacji dla wewnętrznych procesów politycznych, drenażu elit i niektórych cechach zarządzania usługami publicznymi. Dominacja ekonomiczna ujawnia się w procesie zdobywania (centrum) lub tracenia (peryferie) przewagi subkomponentu ekonomicznego wobec politycznego i kulturowego. Procesy kulturowe charakteryzujące ośrodki typu centralnego to

${ }^{2}$ Szczególnie ważny w naukach społecznych wydaje się autorce aspekt tego rodzaju pracy metateoretycznej, ponieważ umożliwia lepszą korespondencję zarówno pomiędzy praktycznymi a teoretycznymi osiągnięciami dyscyplin, jak i pomiędzy poszczególnymi pracami badawczymi. 


\begin{tabular}{|c|c|c|c|}
\hline 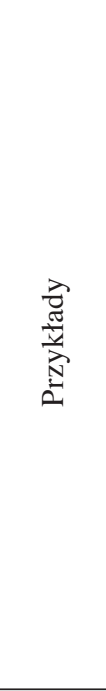 & 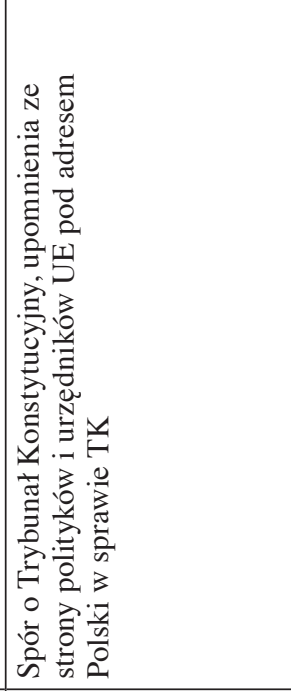 & 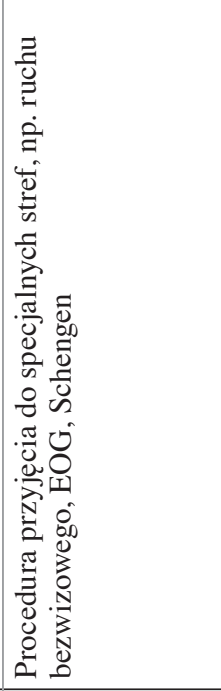 & 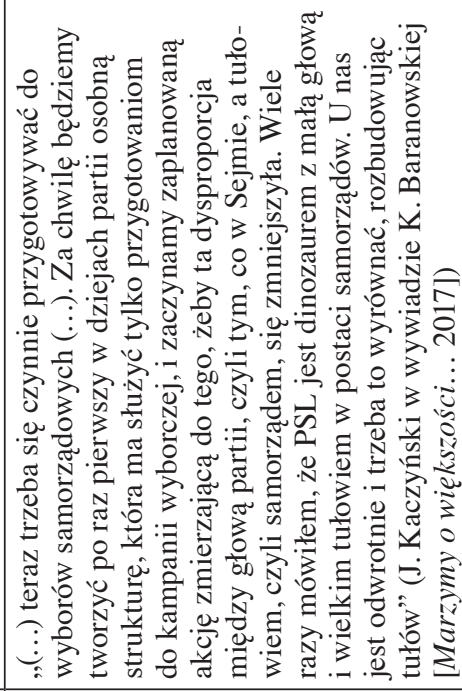 \\
\hline 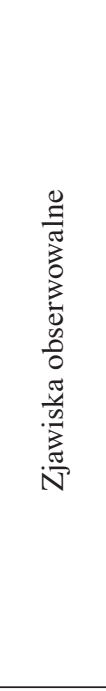 & 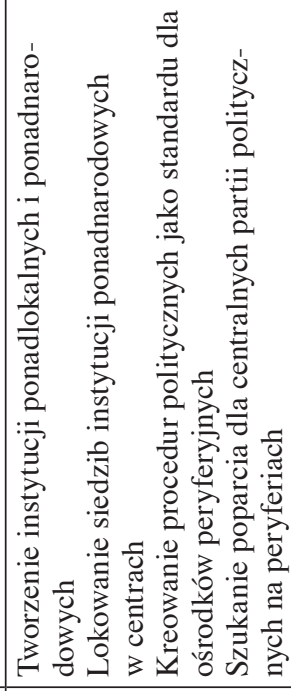 & 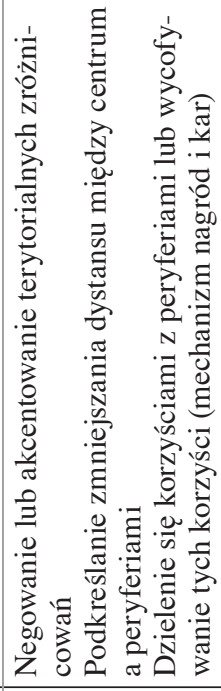 & 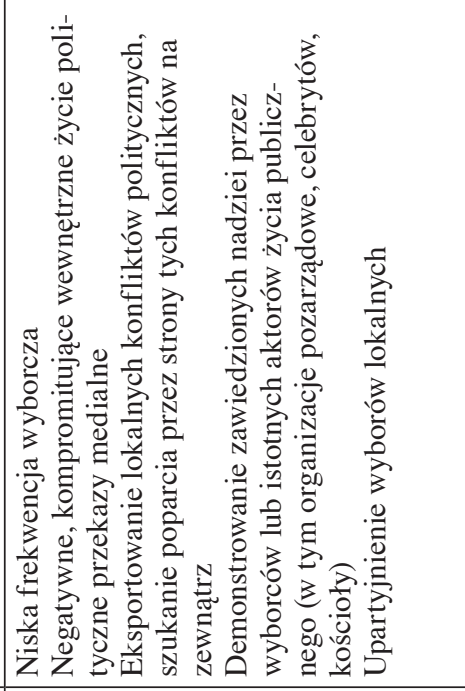 \\
\hline $\begin{array}{l}\tilde{U} \\
\mathbb{0} \\
0\end{array}$ & 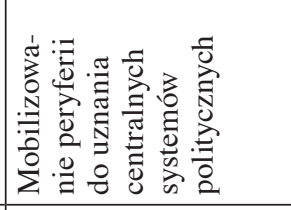 & 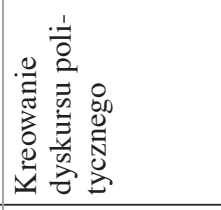 & 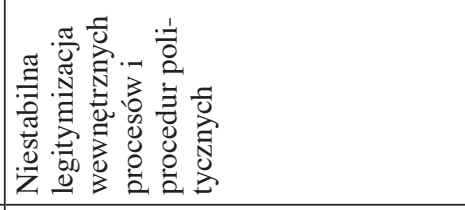 \\
\hline 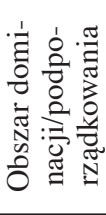 & 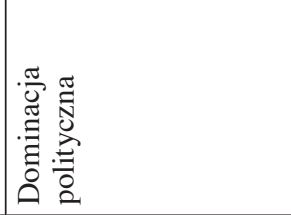 & & 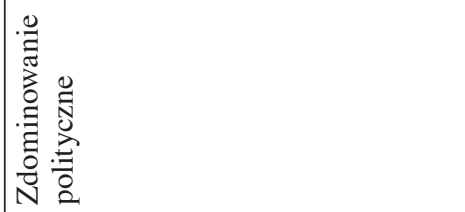 \\
\hline
\end{tabular}




\begin{tabular}{|c|c|c|c|}
\hline 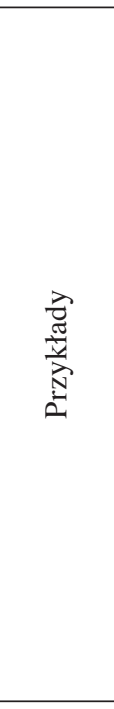 & 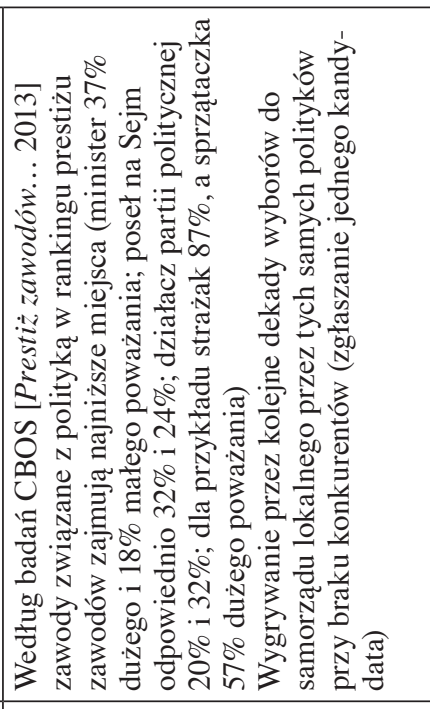 & 1 & 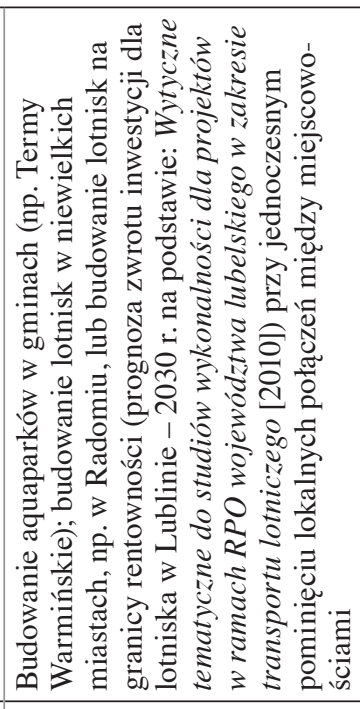 \\
\hline 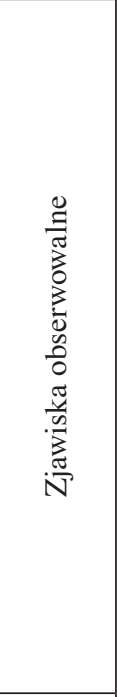 & 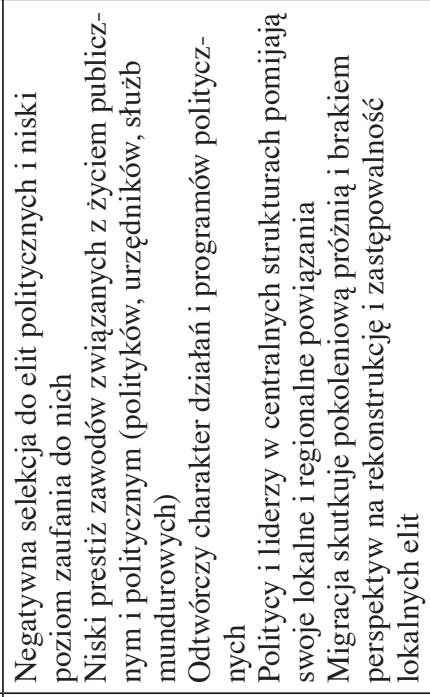 & 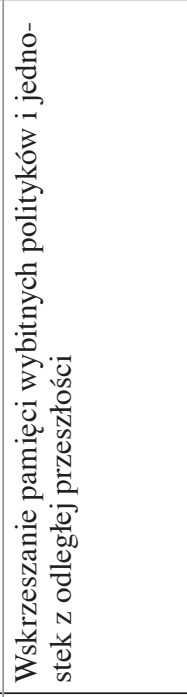 & 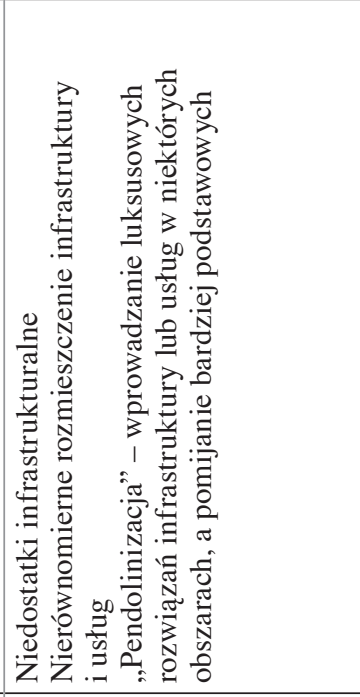 \\
\hline 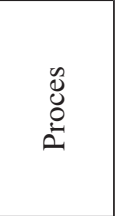 & 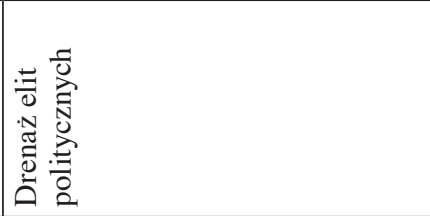 & 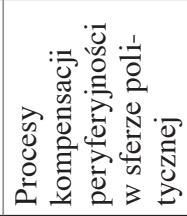 & 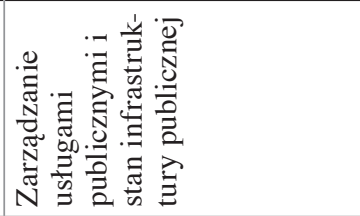 \\
\hline 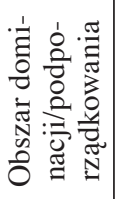 & & & \\
\hline
\end{tabular}




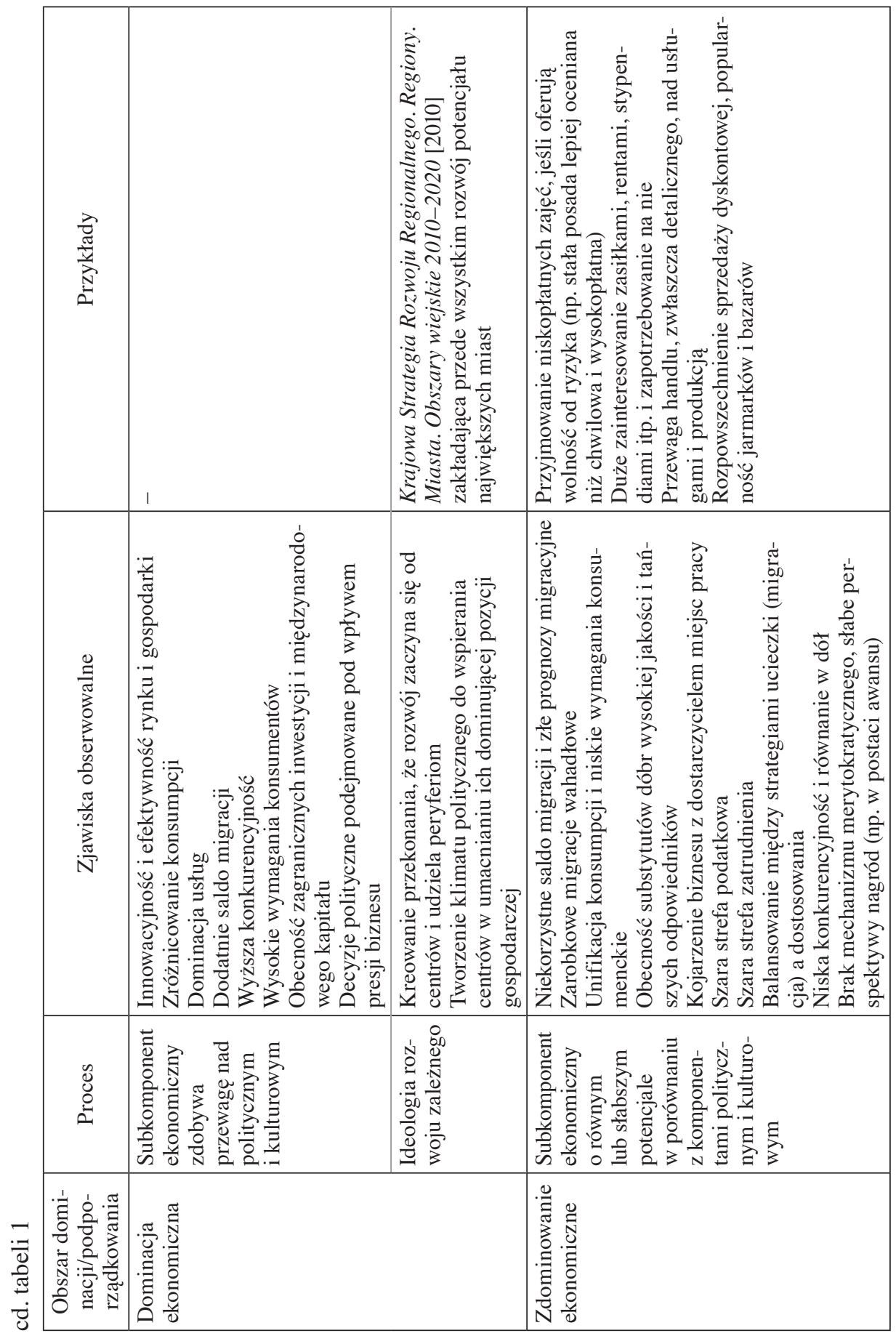




\begin{tabular}{|c|c|c|c|c|}
\hline 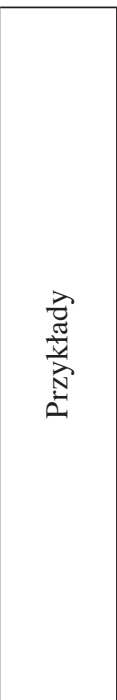 & & 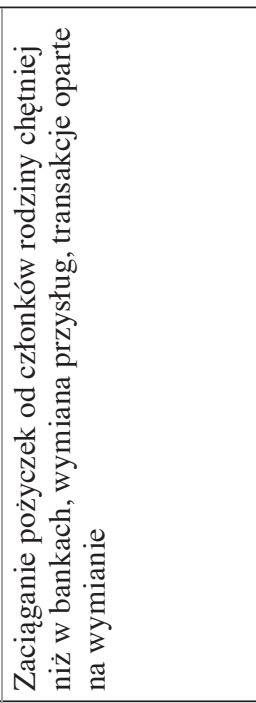 & 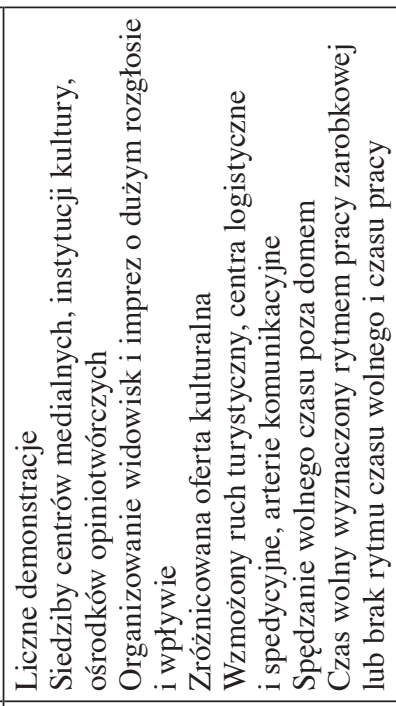 & 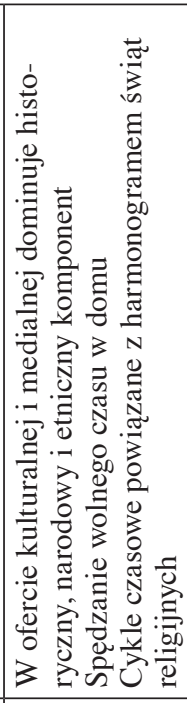 \\
\hline 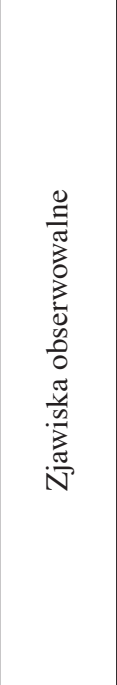 & 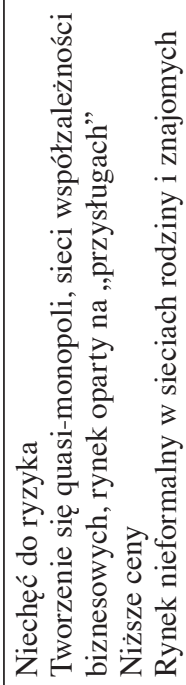 & 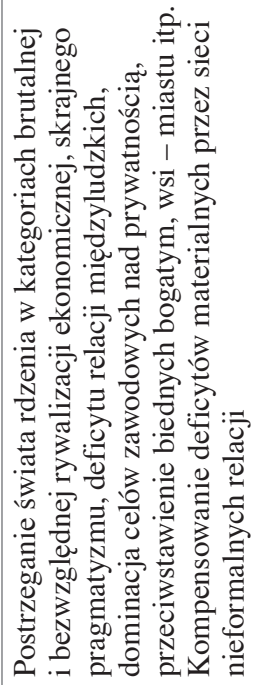 & 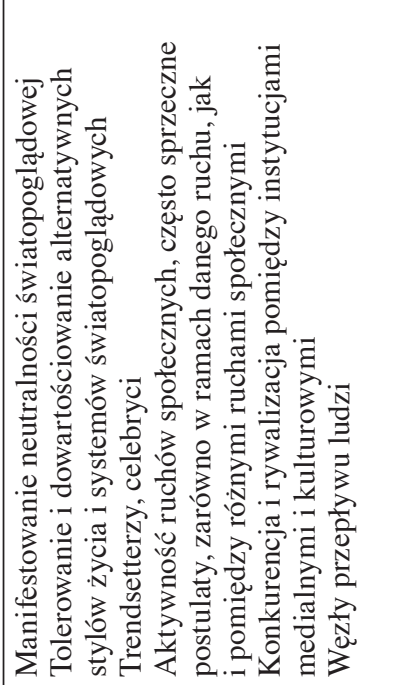 & 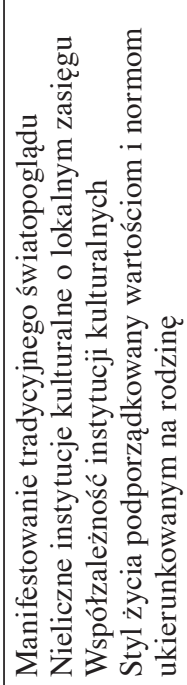 \\
\hline 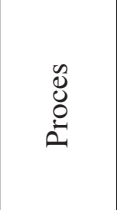 & & 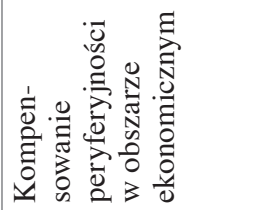 & 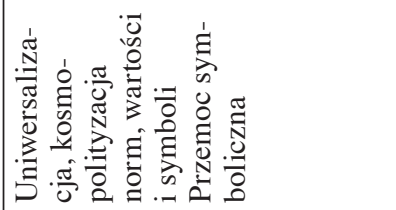 & 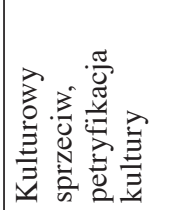 \\
\hline 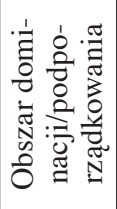 & & & 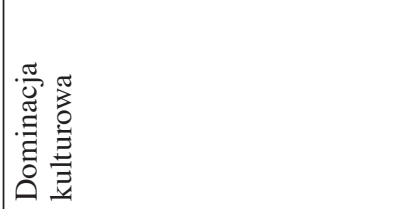 & 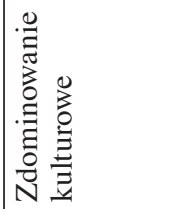 \\
\hline
\end{tabular}




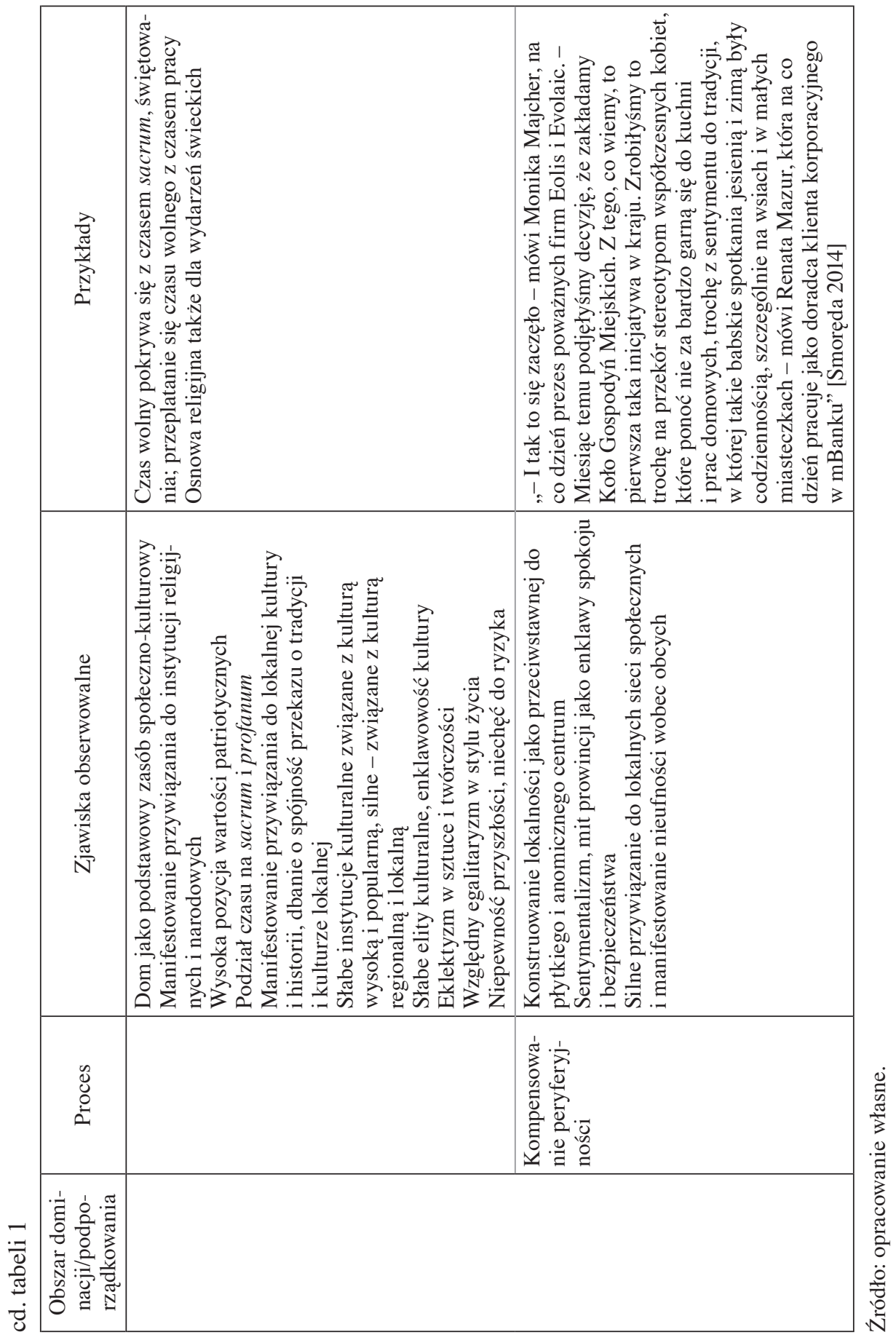


kosmopolityzacja i uniwersalizacja systemów aksjonormatywnych oraz stosowanie przemocy symbolicznej typu peryferyjnego - tradycjonalizacja i petryfikacja wzorów kulturowych.

\section{Wnioski}

Na podstawie przeprowadzonych rozważań sformułować można następujące wnioski dotyczące dalszych badań nad relacjami centro-peryferyjnymi.

1. Rama centrów i peryferii może być użyteczna do badania i wyjaśniania procesów koncentracji i polaryzacji przestrzennych, o ile będzie stosowana krytycznie i niedogmatycznie. Przedstawione w pierwszej części artykułu zastrzeżenia do tej typologii wymagają uwzględnienia. Interpretacja i dobór obserwowanych zjawisk do analizy również wymagają ostrożności. Łatwo bowiem używać tej ramy jako klucza do ideologii i polityki. Jest ważna szczególnie dla badań nad rozwojem, ponieważ pozwala zrozumieć, dlaczego rozwój nie powinien być traktowany ani jako cel, ani norma sama w sobie (autotelicznie), ale jako cel instrumentalny.

2. W obszarze badań empirycznych szczególnie interesujący jest proces kompensacji peryferyjności. Ten proces autorka uważa za kluczowy dla ramy centro-peryferyjnej. Istotność procesu kompensacji peryferyjności potwierdza bowiem status peryferii i ujawnia kierunek relacji dominacji. Kompensacja peryferyjności przebiega jednokierunkowo, występuje tylko w obrębie peryferii i nie jest potrzebna centrom. Ponieważ rama centrum-peryferie ma charakter arbitralny i dialektyczny (to, co jest centrum wobec niektórych obrzeży, może zaliczać się jednocześnie do peryferii wobec innego rdzenia; np. Warszawa spełnia kryteria peryferii wobec ośrodków UE i kryteria centrum wobec innych miejscowości w Polsce), to proces kompensacji wydaje się najbardziej użyteczny do diagnozowania, z jakim kierunkiem dominacji i charakterem peryferyjności mamy do czynienia w przypadku danej jednostki analizy.

3. Badanie relacji centro-peryferyjnych wydaje się bardzo złożonym zagadnieniem i powinno uwzględniać wiele krzyżujących się pól i relacji oraz dialektyczność tych ujęć. Wyodrębnienie aspektu politycznego, ekonomicznego i kulturowego wydaje się czytelne i użyteczne.

4. Same układy terytorialne takie jak odległość czy rozmiar porównywanych ośrodków same w sobie nie są wystarczająco diagnostyczne. Coraz częściej występujący charakter sieciowy relacji układów terytorialnych, decyzyjnych, finansowych czy kulturowych zmniejsza znaczenie czynników ilościowych na rzecz jakościowych. 
5. Relacje dominacji pomiędzy rdzeniem a obrzeżem nie są determinowane, lecz podlegają ciągłym renegocjacjom i redefinicjom. W obszarze politycznym dominacja wyraża się przez inkorporowanie struktur i elit peryferyjnych do układów centralnych (na peryferiach może to być odbierane jako „zdrada elit”), w płaszczyźnie ekonomicznej i gospodarczej dominacja rdzenia przejawia się w transferowaniu mniej innowacyjnych dóbr i usług do obrzeży oraz praktyki offshoringu i outsourcingu. W płaszczyźnie kulturowej dochodzi natomiast do debat i konfliktów związanych z kluczowymi normami i wartościami społecznymi i indywidualnymi. Peryferie preferują tradycyjne systemy aksjonormatywne, podczas gdy centra muszą radzić sobie z wchłanianiem zróżnicowanych hierarchii napływających z często odmiennych kulturowo ośrodków satelickich.

6 . We współczesnym dyskursie publicznym dominuje dialektyka podporządkowania ekonomii pozostałych pól - politycznego i kulturowo-symbolicznego. W tym polu ośrodki peryferyjne zazwyczaj dysponują najmniejszym potencjałem. Obszarem, w którym istnieje szansa na zbudowanie przewag peryferii, jest obszar kulturowo-symboliczny. Silną stroną tego obszaru jest stabilność systemów aksjonormatywnych i dość głęboka internalizacja norm i wartości przechowywanych w układach lokalnych. Słabą stroną jest natomiast zgeneralizowany brak zaufania i niepewność dotycząca przyszłości ograniczająca mieszkańców peryferii w zaangażowaniu się w relacje o innych podstawach niż rodzina i krąg najbliższych przyjaciół i sąsiadów. Zachowanie jednolitego wzorca normatywnego staje się na peryferiach podstawową strategią wzmacniania poczucia bezpieczeństwa i własnej wartości kosztem braku gotowości poznawania nowych modeli kulturowych i szukania w nich inspiracji do tworzenia innowacji.

\section{Literatura}

Bajerski A. [2006], Problemy wydzielania peryferii społeczno-gospodarczych, „Przegląd Prawniczy, Ekonomiczny i Socjologiczny", vol. XXL, z. 2.

Bloom D.E., Canning D. [2009], Reproductive Health and Human Rights: The Way Foward, University of Pennsylvania Press, Pennsylvania.

Casanova J. [1994], Public Religions in the Modern World, University of Chicago Press, Chicago.

Chess-Dunn Ch., Taylor P., Arrighi G., Cox R., Overbeek H., Gills B., Frank A.G., Modelski G., Wilkinson D. [1994], Hegemony and Social Change, „Mershon International Studies Review", vol. 38, nr 2, https://doi.org/10.2307/222747.

Eisenstadt S.N. [2008], Multiple Modernities [w:] Reader on Modern Sociology, eds L.G. Titarenko, G.N. Sokolova, Tesey, Minsk.

Ferrara P. [2015], The Concept of Periphery in Pope's Francis Discourse: A Religious Alternative to Globalization?, „Religions”, vol. 6, nr 1, www.mdpi.com (data dostępu: 16.08.2017). 
Frank A.G. [1966], The Development of Underdevelopment, „Monthly Rewiew”, vol. 18, $\mathrm{nr}$ 4, https://doi.org/10.14452/mr-018-04-1966-08_3.

Hirschman A.O. [1958], The Strategy of Economic Development, Yale University Press, New Haven.

Jałowiecki B., Kapralski S. [2011], Peryferie i pogranicza jako interdyscyplinarny obszar badawczy [w:] Peryferie i pogranicza. O potrzebie różnorodności, red. B. Jałowiecki, S. Kapralski, Scholar, Warszawa.

Kisiała W., Stępiński B. [2013], Rola obszarów metropolitalnych w polityce regionalnej i rozwoju lokalnym, Wydawnictwo Uniwersytetu Ekonomicznego w Poznaniu, Poznań.

Krajowa Strategia Rozwoju Regionalnego. Regiony. Miasta. Obszary wiejskie 2010-2020 [2010], Ministerstwo Rozwoju Regionalnego, Warszawa.

Kurczewska J. [2013], Peryferyjność $w$ doświadczeniach jednostek (trzy argumenty na rzecz tezy o przydatności perspektywy indywidualnej $w$ studiach nad centrami, peryferiami i pograniczami) [w:] Polska Wschodnia i orientalizm, red. P. Zarycki, Scholar, Warszawa.

Latour B. [1999], Pandora's Hope: Essays on the Reality of Science Studies, Harvard University Press, Cambridge.

Lipset S., Rokkan S. [1967], Party Systems and Vote Alignments. Cross-national Perspectives, Free Press, New York.

Losego P., Arvanitis R. [2008], Science in Non-hegemonic Countries, ,Revue d'anthropologie de connaissances", vol. 2, nr 3, https://doi.org/10.3917/rac.005.0343.

Marzymy o większości konstytucyjnej. J. Kaczyński w wywiadzie K. Baranowskiej [2017], „Do Rzeczy”, 6-17 lutego 2017.

Payne A., Philips N. [2011], Rozwój, Sic!, Warszawa.

Perroux F. [1950], Economic Space. Theory and Aplications, „Quarterly Journal of Economics", vol. 64, nr 1, https://doi.org/10.2307/1881960.

Pogonowska B. [2007], Legitymizacja wyzysku [w:] Wyzysk ekonomiczny współcześnie, red. K. Sosenko, Wydawnictwo Akademii Ekonomicznej w Krakowie, Kraków.

Prestiż zawodów. Komunikat z badań CBOS BS/164/2013, Warszawa http://www.cbos.pl/ SPISKOM.POL/2013/K_164_13.PDF (data dostępu: 31.01.2017).

Smoręda M. [2014], Grupa Kielczanek założyła pierwsze w Polsce Koło Gospodyń Miejskich. Do grona superbabek chcq dołaczyć kolejne, http://www.echodnia.eu/ swietokrzyskie/wiadomosci/kielce/art/8089178,grupa-kielczanek-zalozyla-pierwsze-w-polsce-kolo-gospodyn-miejskich-do-grona-superbabek-chca-dolaczyc-kolejne,id,t. html (data dostępu: 31.01.2017).

Tickner A.B [2013], Core, Periphery and (Neo)Imperialist International Relations, „European Journal of International Relations”, vol. 19, nr 3, https://doi.org/10.1177/ 1354066113494323.

Wilkinson R., Pickett K. [2011], Duch równości. Tam, gdzie panuje równość, wszystkim żyje się lepiej, Czarna Owca, Warszawa.

Wytyczne tematyczne do studiów wykonalności dla projektów w ramach RPO województwa lubelskiego w zakresie transportu lotniczego [2010], Urząd Marszałkowski Województwa Lubelskiego, Departament Strategii i Rozwoju Regionalnego, Lublin.

Zarycki P. [2002], Four Dimensions of Center-Periphery Conflict in the Polish Electoral Geography [w:] Social Change. Adaptation and Resistance, red. T. Klonowicz, G. Wieczorkowska, Warsaw University - Institute for Social Studies, Warszawa.

Zarycki P. [2009], Peryferie. Nowe ujęcie zależności centro-peryferyjnych, Scholar, Warszawa. 


\section{Centres and Peripheries as an Analytical and Conceptual Framework} (Abstract)

The aim of the article is to investigate the centre - periphery framework for its practical usefulness as an analytical and explanatory tool to study the processes of space, cultural (including symbolic), political, and economic concentration and polarisation.

There are two parts. The first examines theoretical problems concerning the application of the centre and periphery. The issues discussed include the fact that these concepts can be arbitrary, while there are many tacit additional assumptions surrounding the concepts of centre and periphery, which seem to make up a universal conceptual framework. The second part investigates the possibility of making a clear typology of centres and peripheries based the dominant processes and observable phenomena that make up the processes (examples are given for some of them). The article is a kind of metatheoretical overview and aims to identify further directions of centres-periphery research.

As a result of the analysis, a list of observable categories comprising the description of centres and peripheries was made. These categories can be the foundation of a typologisation and operationalisation in empirical research. The concept of ,,periphery compensation" is of particular significance. It confirms the status of peripheries and reveals the direction of a dominant relation.

Keywords: centre, peripheries, compensation of peripheral status, development. 